\title{
An Application of Game Theory in Determining Competitive Strategies on Smartphone Products
}

\author{
Destia Anisya Ramdani ${ }^{1 *}$, Jauhari Arifin ${ }^{2}$ \\ ${ }^{1,2}$ Industrial Engineering, Faculty of Engineering, Universitas Singaperbangsa Karawang \\ *Correspondence email: destia.ramdani11@gmail.com
}

Received: 12 Januari 2021

Approved: 15 Februari 2021

\begin{abstract}
In this modern era where technologies growing rapidly, various businesses are increasingly competitive as well as businesses in telecommunications. Nowadays, most of the companies manufacture sophisticated smartphones in which each of them has its own specialties to attract consumers. This studi aims to identify how each type of smartphone show its excellence so that it can make people interested. The purpose of this study is to find out how the implementation of game theory in determining the competitive strategies of each smartphone products. The results that is obtained from the Dominant method and the Maximin - Minimax method show that the optimal solution strategy obtained is 3, where 3 means explaining that the optimal solution from Xiaomi is the Price strategy $(\mathrm{H})$, while Oppo with the quality strategy $(\mathrm{K})$.
\end{abstract}

Keywords: dominant strategy, game theory, maximim-minimax, smartphone, oppo

\begin{abstract}
Abstrak
Seiring perkembangan zaman teknologi semakin canggih, berbagai bisnis semakin bersaing ketat, begitu juga dengan bisnis yang bergerak pada bidang telekomunikasi. Saat ini banyak sekali perusahaan yang mengeluarkan smartphone yang semakin canggih, setiap smartphone memiliki keunggulannya masingmasing yang menjadi daya tarik para konsumennya. Pada penelitian kali ini akan melihat bagaimana setiap jenis smartphone memenangkan keunggulannya agar para konsumen tertarik. Tujuan penelitian ini untuk melihat bagaimana penerapan teori permainan dalam penentuan strategi bersaing dari masingmasing produk smartphone. Dari hasil penelitian dapat dilihat bahwasanya hasil yang diperoleh dari metode dominan dan metode Maximin - Minimax strategi solusi optimal yang didapat adalah 3, dimana 3 ini artinya menjelaskan bahwa solusi optimal dari Xiaomi adalah strategi Harga $(\mathrm{H})$, sedangkan Oppo dengan strategi kualitasnya $(\mathrm{K})$.
\end{abstract}

Kata Kunci: dominan strategi, teori permainan, maximin-minimax, smartphone,oppo

\section{Introduction}

The development of technology effects all business fields competing to promote their products, both companies engaged in service and in product. Marketing is a strategy that is usually carried out in a business [1]. Every company need to consider about how marketing management is well managed and to attract consumers to buy their products so that sales can reach the target and the company gain he profit [2]. Basically, marketing aims to distribute or sell product manufactured to consumers and to provide the profits in sales activities [3].

Smartphone is a tool used to ease the communication process especially in a remote region. Sending messages and files can be direct and quick by using smartphone. Moreover, it can also be used to play games, watch videos and entertain the customers [2]. Currently, the level of smartphone users is increasing, as consequence of this most of companies increase the aspect of their product and it effect on level of competition in the market [2]. Smartphones are very competitive in various aspects, such as in terms of price, quality, promotions and features embedded on them.

Every smartphone product competing in the market has its strengths and weakness. Game theory analysis is used to identify what consumer interest in purchase a smartphone. Game theory is a science to determine, formulate, and study conflict situations in order to obtain optimal decisions which is made in a mathematical model [4]. Game theory is also a mathematical technique and logical thinking in determining decisions in order to win the competition and can be found from the pay off value (the expected value of using the strategy) [5]. 
Game theory has been widely used in previous research. Including research conducted by [2] with the research title "Implementation of Game Theory in Determining Competitive Strategies in Smartphone Products". In this study, researcher conducted the research on various smartphone products with a strategy of product strength for each product. The research was conducted by collecting questionnaire and the data obtained were calculated using the pure game theory method. The finding of this research reveals that the optimal strategy used by the Xiaomi and Samsung companies so that competition runs in balance is the use of pure strategy, where Xiaomi uses a price strategy, and Samsung responds using a quality strategy. The other strategies according to game theory could lead to reduced profit for Xiaomi and increased loss for Samsung. For that reason, this research will look at how to determine competitive strategies in smartphone products using implementing game theory by targeting smartphone users around the researcher (college students).

\section{Literature Review}

\subsection{Definition of Game Theory}

Game theory is an optimal decision-making method combined with an applied mathematical model that aims to identify interactions between individuals or other structures (such as teams or institutions) from different competitive situations [6][7].

Game theory is an algorithm to analyze the strategy between players in a competitive situation to achieve a nash equilibrium condition. Nash equilibrium is the best condition with the strategy used by each player [8].

Game theory is a mathematical tool that analyzes strategic interactions among many decision makers. The three main components of the strategic form game model are [9] :

a. A limited set of players, denoted by $\mathrm{N}$

b. A set of actions, denoted by Ai, for each player $\mathrm{i}$

c. payoff / utility function, denoted by, ui: A $\square$ R, which measures

the result for player is determined by the actions of all players, $\mathrm{A}=\mathrm{xi \in \textrm {N }} \mathrm{Ai}$

Game theory is a mathematical model used in situations of conflict or competition between various interests that compete each other. In the game, the participants are competitors. The advantage for one is the loss for the others. The game models can be differentiated based on the number of players, the amount of profit or loss, and the number of strategies used in the game. When the number of players is two, the game is called a two player game. When the profit or loss is equal to zero, it is called the zero sum game [10].

Table 1. The example matrix of a zero-sum two-player game

\begin{tabular}{cccc}
\hline & \multicolumn{3}{c}{ Player B } \\
\cline { 2 - 4 } Player A & B1 & B2 & B3 \\
\cline { 2 - 4 } A1 & 6 & 9 & 2 \\
A2 & 8 & 5 & 4 \\
\hline
\end{tabular}

\subsection{Elements in the Matrix of Game}

There are 7 kinds of elements in the matrix of game theory, including [11]:

1. The numbers in the pay-off matrix, or usually called as the game matrix, represent the results (or pay offs) of different playing strategies. In a two-player zero-sum game, positive numbers represent a gain for the line player (or maximizing player), and a loss for the column player (or minimizing player).

2. A game strategy is a suite of activities or a comprehensive plan from a player, as a reaction to actions that may be taken by other players who are competitors.

3. The rules of the game describe the framework by which the players choose their strategy.

4. Game score is the estimated result of each game or average pay off over a suite of games, in which both players follow or use their best or optimal strategy. A game is said to be "fair" if the value is zero, where no player gains or wins. Player is said to be "unfair" if the value is not zero.

5. A strategy is said to be dominant if every pay off in the strategy is superior to any related payoff in an alternative strategy 
6. An optimal strategy is a suite of activities or a comprehensive plan, which puts a player in the most advantageous position regardless of the activities of his competitors.

7. The objective of the game model is to identify the optimal strategy or plan for each player (Snyder).

\subsection{General Provisions of Game Theory}

There are five general provisions of game theory, namely [6]:

1. Each player plays rationally, with the assumption that has the same intelligence, and the same goal is maximizing payoff, with maximum and minimum criteria.

2. Consisting of a minimum of 2 players, the advantage for one player is a loss for the other player.

3. The arranged table shows the player row gains, and column player losses.

4. The game is said to be fair if the final result is zero (0), no one wins / loses.

5. The purpose of this game theory is to identify the most optimal strategy.

\subsection{Strategies of Game Theory}

\section{A. Pure Strategy}

The optimal results from a game that has a saddle point can be obtained by using a pure strategy. Saddle point is a kind of balance point between the game values of the two players [12].

In Pure Strategy games, the optimal strategy for each player is using a single strategy. Line players identify their optimal strategy through maximin criteria (maximin) and column players with minimum criteria (minimax) [13].

If the minimum value is not the same as the maximum value, therefore the game cannot be solved with a pure strategy, you must use a mixed strategy [14]. Completion steps include:

a. Find the values of row minimum and column maximum.

b. From the minimum values of each row, find the maximum value or what is called the maximum value. Meanwhile, from the maximum value of the column, determine one minimum value as the minimum value.

c. If the minimum value is the same as the maximum value, it means that the most optimal strategy for each player has been found.

\section{B. Mixed Strategy}

Table 2. Column and row player positions

\begin{tabular}{|c|c|c|c|}
\hline \multirow{2}{*}{ Pemain A } & \multicolumn{2}{|c|}{ Pemain B } & \multirow{2}{*}{ Minimum Baris } \\
\hline & B1 & $\mathrm{B} 2$ & \\
\hline $\mathrm{A} 1$ & 2 & 5 & 2 \\
\hline A2 & 6 & 1 & 1 \\
\hline Maksimum Kolom & 6 & 5 & \\
\hline
\end{tabular}

Because the maximum value is still not the same as the minimum value, the completion of this strategy game can be done using the graph method, the matrix algebra method, and the analytical method [15]. The following is an explanation of the three methods:

a. Metode Analitis

In this pattern the probability distributions are determined for the different strategies. The payoff probability values can be calculated in the following manner:

1) For player $A$, assume that using $A 1$ strategy with probability $P$, and for $A 3$ strategy the probability is 1-p. If the strategy used by B is B1 then A's expected profit is: $2 p+6(1-P)=$ $6-4 p$. If B uses the B2 strategy, then A's expected profit is: $5 p+1(1-p)=1+4 p$.

2) For player $B$ the expected pay off is calculated for player B. The probability for strategy B1 is $\mathrm{q}$ and $\mathrm{B} 2$ is 1 - $\mathrm{q}$. Then:

The disadvantages of $\mathrm{B}$, if A uses the A1 strategy are:

$2 q+5(1-q)=5-3 q$

Disadvantages of $\mathrm{B}$, if A uses A3 strategy are:

$6 q+1(1-q)=1+5 q[15]$

b. Graph Method

All $2 \times \mathrm{n}$ games (this is, row players have two strategies and column players have $\mathrm{n}$ strategies) and $m \times 2$ games (this is row players have $m$ strategies and column players have 2 strategies) can be 
completed graphically. To be able to finish this game graphically, the first dimension of the game matrix should be 2. about this method can be read in book two (Snyder).

c. Linear Programming Method

Previous methods have limited scope. The linear programming methods can be used to complete a mixed strategy game of $3 \times 3$ or larger dimensions. To explain this technique, the example of a two player game with the number of zeros is used in the table above. The notation used:
$\mathrm{V} \quad:$ The value of the game the expected profit value for player $A$ is:
$2 \mathrm{X} 1+6 \mathrm{X} 2 \geq \mathrm{V}$.
(if player B uses strategy B1 onwards)
$5 \mathrm{X} 1+1 \mathrm{X} 2 \geq \mathrm{V}$.
(if player B uses B2 strategy so on) [15].

$\mathrm{X} 1$ and X2 : Probability of selecting strategy A1 and strategy A3

Y1 and Y2 : The probability of choosing strategy B1 and strategy B2

With $\mathrm{A}$ as the maximizing player, the profit expected by $\mathrm{A}$ is in a sign of inequality $>$. Therefore

\section{Research Methodology}

The steps carried out in this game theory research include:

1. Determine the marketing strategy used by smartphone manufacturers. In this study, three strategies are used by smartphone manufacturers, namely the price, product quality and product promotion strategy.

2. Collect primary data in the form of the most widely used smartphone brands. Smartphone data in this study were obtained from questionnaires distributed to 30 students.

3. Perform calculations, the first thing that is done in calculating is determining the variables that will be used in the calculation.

4. Determination of Maximin-Minimax. After determining the variables to be used, then for the determination of Maximin-Minimax, the row players and column players are determined and the strategy used. After it has been determined, describe it in the Pay-off matrix table.

5. After the maximin and minimax are determined, the optimal strategy is calculated using the pure strategy method with the Dominant strategy and Maximin-Minimax.

6. Analyze the results and conclusions.

\section{Results and Discussion}

\subsection{Data Collection}

Currently, the competition in the business world seems to be tight especially in the Smartphone market. Therefore, we want to recognise smartphone products that are in a great demand and the strengths these products, since each of the products might have its specialities.

In this case, we took samples from several types of smartphones that might have competing rate in the market. The sampel of Smartphone brands includes Samsung, Xiaomi, Oppo, Vivo, Huawei, etc (Iphone). Each of these products has its advantages or strategies, both in terms of price, quality, or promotion. Of the many respondents in questionnaire, there are only 30 respondents taken as the sample, and following data was obtained:

Table 3. Results of the smartphone brand questionnaire

\begin{tabular}{ccccc}
\hline $\begin{array}{c}\text { Smartphone } \\
\text { Brand }\end{array}$ & Price & Quality & Promotion & Total \\
\hline Samsung & & 2 & & 2 \\
Xiaomi & 7 & 5 & 3 & 15 \\
Oppo & 2 & 4 & 1 & 7 \\
Vivo & & 3 & 1 & 4 \\
Huawei & & 2 & & 0 \\
Iphone & & & & 2 \\
\hline Total & & & & 30 \\
\hline
\end{tabular}

The results of this questionnaire sorted from those who obtain the largest number, then the following table is the arrangement of the largest number: 
Table 4. Structure of the questionnaire results from the largest number

\begin{tabular}{c|cccc}
\hline $\begin{array}{c}\text { Smartphone } \\
\text { Brand }\end{array}$ & Price & Quality & Promotion & Total \\
\hline Xiaomi & 7 & 5 & 3 & 15 \\
Oppo & 2 & 4 & 1 & 7 \\
Vivo & & 3 & 1 & 4 \\
Samsung & & 2 & & 2 \\
Dll (Iphone) & & 2 & & 0 \\
Huawei & & & & 30 \\
\hline Total & & & & \\
\hline
\end{tabular}

From a sample of 30 data from the questionnaire results, it can be seen that the most widely used Smartphone brands are Xiaomi, consisting of 15 users, followed by Oppo, 7 users out of 30 samples. Therefore, the competitive strategies of these two smartphone brands will be analyzed in this research.

\subsection{Data analysis}

1. Problem Definition

In this case we will use the Pure Strategy Method. There are 3 methods of Pure Strategy, namely Trial, Dominant Strategy and Maximin-Minimax, but this time we will use pure strategy with the Dominant Strategy and Maximin-Minimax methods only. Here's the solution.

2. Model Develepment

\section{Criteria:}

Xiaomi, Oppo : : Smartphone Brands

Current status / condition : Number of Xiaomi customers 15 out of 30 and Number of customers Oppo 7 of 30

Symbol: H (Pricing Strategy), K (Quality Strategy), P (Promotion Strategy).

Destination function: Xiaomi (Row) - Oppo (Column) = Pay Off Matrix.

\section{Limitation:}

a. Xiaomi is a row player (who gains) and Oppo is a column player (who loses).

b. Determines the maximin value for the row player (Xiaomi) and Minimax for the column player (Oppo).

3. Model Breakdown

The determination of the competitive strategy in the game theory is carried out using the acquisition value table from Xiaomi and Oppo with the following steps:

a. Xiaomi is line player (who gains) and Oppo is column player (who loses). The reason is because Xiaomi ranks first in the smartphone brand user from 30 respondents we took from the questionnaire, while Oppo is in the second position of users.

b. The strategy used by the two smartphone products is symbolized by $\mathrm{H}$ as the price strategy, $\mathrm{K}$ as the quality strategy, and $\mathrm{P}$ as the promotion strategy.

c. The value in the pay off matrix table is the difference between Xiaomi's total acquisition on each strategy minus Oppo's total acquisition on each strategy.

d. Determines the maximin value for the row player (Xiaomi) and Minimax for the column player (Oppo). Maximin is the maximum value from the minimum value of each Xiaomi strategy, while Minimax is the minimum value of the maximum value for each strategy of Oppo.

e. Determine the optimal strategy for Xiaomi and Oppo with a pure strategy method with Dominant Strategy and Maximin - minimax. 
This is the completion:

\subsection{Dominan Strategy}

Table 5. Pay off Matrix table

\begin{tabular}{c|cc|cccc}
\hline \multicolumn{1}{c}{} & & & \multicolumn{4}{c}{ Oppo } \\
\cline { 3 - 6 } \multicolumn{1}{c}{} & & & 2 & 4 & 1 \\
\hline \multirow{3}{*}{ Xiaomi } & & & $\mathrm{H}$ & $\mathrm{K}$ & $\mathrm{P}$ \\
& 5 & $\mathrm{H}$ & 5 & 3 & 6 \\
& 5 & $\mathrm{~K}$ & 3 & 1 & 4 \\
& 3 & $\mathrm{P}$ & 1 & -1 & 2 \\
\hline
\end{tabular}

\section{Stage 1}

Based on Xiaomi's point of view, it can be noticed that the elimination of the one whose value is likely to be really less than any of the angles (in the row). The P line is eliminated, because the P line tends to be smaller than the $\mathrm{H}$ and $\mathrm{K}$ lines.

Table 6. Elimination of Line $\mathrm{P}$

\begin{tabular}{|c|c|c|c|c|c|}
\hline & & & \multicolumn{3}{|c|}{ Oppo } \\
\hline & & & 2 & 4 & 1 \\
\hline & & & $\mathrm{H}$ & K & $\mathrm{P}$ \\
\hline & 7 & $\mathrm{H}$ & 5 & 3 & 6 \\
\hline Xiaomi & 5 & $\mathrm{~K}$ & 3 & 1 & 4 \\
\hline
\end{tabular}

\section{Stage 2}

1. In stage 1 , line $P$ has been eliminated.

2. Since Oppo's goal is minimum pay off, Oppo is looking for a small column.

3. Columns with small values are more dominant and are able to eliminate large value columns.

Table 7. Elimination of column $\mathrm{P}$

\begin{tabular}{|c|c|c|c|c|}
\hline & & & \multicolumn{2}{|c|}{ Oppo } \\
\hline & & & 2 & 4 \\
\hline & & & $\mathrm{H}$ & K \\
\hline & 7 & $\mathrm{H}$ & 5 & 3 \\
\hline Xiaomi & 5 & $\mathrm{~K}$ & 3 & 1 \\
\hline
\end{tabular}

\section{Stage 3}

1. In stage 2 column $P$ has been eliminated.

2. Since Xiaomi's goal is maximum pay off, therefore Xiaomi is looking for a big line.

3. More dominant large value lines are able to eliminate low value rows.

4.

Table 8. Elimination of Line K

\begin{tabular}{|c|c|c|c|c|}
\hline & & & \multicolumn{2}{|c|}{ Oppo } \\
\hline & & & 2 & 4 \\
\hline & & & $\mathrm{H}$ & $\mathrm{K}$ \\
\hline Xianmi & 7 & $\mathrm{H}$ & 5 & 3 \\
\hline
\end{tabular}




\section{Stage 4}

1. At stage 3, Line $\mathrm{K}$ was eliminated.

2. Since Oppo's goal is minimum pay off, Oppo is looking for a small column.

3. Columns with small values are more dominant and was able to eliminate large value columns.

4. Then column $\mathrm{H}$ will be eliminated, then the game value will be obtained (the optimal solution) is 3 , where 3 explaining that the optimal solution from Xiaomi is the H or Price strategy, while Oppo with $\mathrm{K}$ or the quality strategy.

Table 9. Results of application of dominant strategies

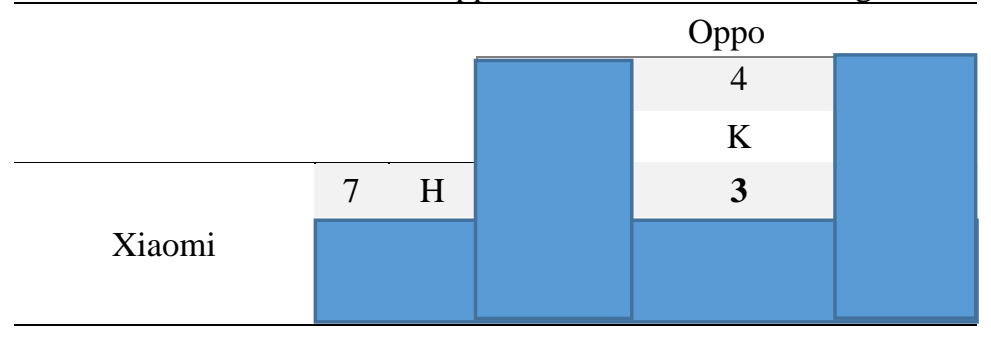

\subsection{Maximin - minimax}

There are saveral aspects needed to be considered to determine the maximin value for line players (Xiaomi) and Minimax for column players (Oppo) to solving the case using this method. Maximin is the maximum value of the minimum gain for each Xiaomi strategy, while Minimax is the minimum value of the maximum value for each Oppo strategy.

Table 10. Maximin acquisition value - minimax

\begin{tabular}{|c|c|c|c|c|c|c|}
\hline & & & \multicolumn{3}{|c|}{ Samsung } & Maximax \\
\hline & & & 2 & 4 & 1 & \\
\hline & & & $\mathrm{H}$ & $\mathrm{K}$ & $\mathrm{P}$ & \\
\hline \multirow{4}{*}{ Xiaomi } & 7 & $\mathrm{H}$ & 5 & 3 & 6 & 3 \\
\hline & 5 & K & 3 & 1 & 4 & 1 \\
\hline & 3 & $\mathrm{P}$ & 1 & -1 & 2 & -1 \\
\hline & \multicolumn{2}{|c|}{ Minimax } & 5 & 3 & 6 & \\
\hline
\end{tabular}

The optimal solution is obtained, which is 3 . The 3 means explaining that the optimal solution from Xiaomi is the $\mathrm{H}$ or Price strategy, while Oppo is with $\mathrm{K}$ or the quality strategy. Results and best strategy for Xiaomi based on Table 7 and Table 8 is to use the H (Price) strategy. Judging from the calculation results in the table, Xiaomi's maximin value is 3,1 and -1 . These values are profit values for Xiaomi. From the three numbers, the biggest advantage is 3 or it can be said that 3 is the smallest disadvantage for Xiaomi when using a pricing strategy. This means that even though the Xiaomi company wants a bigger profit, it will still only get a profit of 3 using the price strategy.

4.3 Meanwhile, the Discussion

The best strategy for Oppo based on Table 7 and Table 8 is to use the K (Quality) strategy. Judging from the calculation results in the table, Oppo's minimax values are 5, 3 and 6 . These values are the losses for Oppo. From the three numbers, the smallest loss is 3, or it can also be said to be a gain of 3 . This choice means that even though the Oppo company wants less losses, it will still only get a loss of 3 by using a quality strategy to respond to Xiaomi's pricing strategy.

\section{Conclusion}

Based on the results of the analysis and discussion, it can be concluded that the pay-off value obtained from the strategy donation method and Maximin - minimax is 3 ( 3 is the value of the game), saddle points $\mathrm{H}, \mathrm{K}$ with the optimum strategy obtained by Xiaomi is Price strategy while Oppo is quality strategy. Optimal strategy is used by the Xiaomi and Oppo companies to make the competition runs in balance from pure strategy method (Dominant Strategy and Maximin-Minimax). Optimal solution obtained from dominant strategy method is 3 . The value of 3 means that the optimal solution from 
Xiaomi is $\mathrm{H}$ or Price strategy, while Oppo with $\mathrm{K}$ or its quality strategy. With the Maximin - Minimax method, the optimal solution obtained is 3 , where 3 means that the optimal solution from Xiaomi is the $\mathrm{H}$ or Price strategy, while Oppo with $\mathrm{K}$ or the quality strategy. Proposals for further research can use software to complete game theory to make it easier to work on.

\section{Bibliography}

[1] D. S. Donoriyanto, "Penentuan Strategi pemasaran produk minuman energi dengan teori permainan (Game Theory) untuk meningkatkan minat konsumen di wilayah Surabaya Timur," Penentuan Strateg. Pemasar. Prod. minuman energi dengan Teor. permainan (Game Theory) untuk Meningkat. minat Konsum. di Wil. Surabaya Timur, vol. 10, pp. 11-18, 2010.

[2] D. Ma'rifah, "Implementasi Game Theory Dalam Penentuan Strategi Bersaing Pada Produk Smartphone," Fokus Bisnis Media Pengkaj. Manaj. dan Akunt., vol. 17, no. 2, pp. 57-61, 2019, doi: 10.32639/fokusbisnis.v17i2.279.

[3] D. Anggraini and N. W. Putra, "Aplikasi Logika Fuzzy Dalam Teori Permainan Untuk Menentukan Strategi Pemasaran ( Studi Kasus : Persaingan Alfamart dan Indomaret )," Semin. Nas. Mat. dan Pendidik. Mat. 2017, pp. 81-87, 2017.

[4] A. Saifuddin, N. K. T. Tastrawati, and K. Sari, "Penerapan Konsep Teori Permainan (Game Theory) Dalam Pemilihan Strategi Kampanye Politik (Studi Kasus: Strategi Pemenangan Pemilukada DKI Jakarta Tahun 201," E-Jurnal Mat., vol. 7, no. 2, p. 173, 2018, doi: 10.24843/mtk.2018.v07.i02.p200.

[5] Y. Budiana and F. N. Khasanah, "Analisis Strategi Kompetisi Antara Jasa Transportasi Online Gojek dan Grab dengan Menggunakan Game Theory (Studi Kasus: Mahasiswa di Pulau Jawa)," J. Mitra Manaj. (JMM Online), vol. 4, no. 1, pp. 16-27, 2020.

[6] A. Rizal, "Implementasi Teori Permainan dalam Strategi Pemasaran Produk Laptop ( Studi Kasus Mahasiswa S1 FMIPA USU )," 2017.

[7] I. A. Fadilla, "Konsep Dasar Bentuk Ekstensif Permainan," 2019.

[8] A. F. Amarullah, Setia Hadi, Tridoyo Kusumastanto, "Aplikasi Game Theory pada Pengelolaan Sumberdaya Pesisir di Selat Sebuku, Kabupaten Kotabaru, Kalimantan Selatan (The Application of Game Theory on Coastal Resources Management at Sebuku Strait, Kotabaru Regency, South Kalimantan)," no. 66, pp. 353-361, 2015.

[9] N. Amalia, "Analisis Pendekatan Game Theory Untuk Pemilihan Kanal Pada Jaringan Radio Kognitif," Transmisi, vol. 20, no. 2, p. 57, 2018, doi: 10.14710/transmisi.20.2.57-63.

[10] Fetty Yudha Winata Sekti, "Kajian metode Brown dan metode program linier dalam teori permainan (permainan dua orang dengan jumlah nilai permainan nol)," 2011.

[11] E. A. Wijayanti, "Penggunaan Teori Permainan Guna Menentukan Strategi Pemasaran Pada Rumah Makan," pp. 57-61, 2012.

[12] M. Jenar, W. Sutopo, and Y. Yuniaristanto, "Pengembangan Model Game Theory Pada Skema Persediaan Penyangga Untuk Menjamin Ketersediaan Dan Kestabilan Harga Komoditas Gula Pasir,”J@Ti Undip J. Tek. Ind., vol. 10, no. 2, 2015, doi: 10.12777/jati.10.2.97-102.

[13] F. Juliyanto and E. Y. Sari, "Analisis Persaingan Perbankan Dengan Game Theory Serta Upaya Meningkatkan Kepuasan Nasabah Dengan Pendekatan Importance Performance Analysis," J. Ilm. Tek. Ind., vol. 5, no. 1, pp. 54-62, 2018, doi: 10.24912/jitiuntar.v5i1.1780.

[14] C. H. Simamora, E. Rosmaini, and N. Napitupulu, "Penerapan Teori Permainan Dalam Strategi Pemasaran Produk Ban Sepeda Motor Di Fmipa Usu," Saintia Mat., vol. 1, no. 2, pp. 129-137, 2013.

[15] Z. E. Ahadi, Modul Pertemuan 7 Game Theory. 2012. 